\title{
A survey of consumer' opinion about consumption and health benefits of fermented plant beverages in Thailand
}

\author{
Chaiyavat CHAIYASUT ${ }^{1}$, Bhagavathi Sundaram SIVAMARUTHI ${ }^{1}$, Netnapa MAKHAMRUEANG ${ }^{1}$, \\ Sartjin PEERAJAN ${ }^{2}$, Periyanaina KESIKA ${ }^{1 *}$
}

\begin{abstract}
Fermented beverages are widely used all over the country. Fermented plant beverages (FPB) are prevalent in Thailand and FPBs are believed to cure and prevent many health oriented problems. The people of Thailand produce many varieties of FPBs in small scale or large scale and consume them in their daily lives. This study is a survey conducted among the representative consumers of FPBs in Thailand to know the consumer's opinion on FPBs, effects and benefits of FPBs, and real status of consumer satisfaction in Thailand. This study revealed that the rationale for the consumption of respective FPBs was to treat their health issues and for the betterment of their health. Most of the consumers of FPBs benefited in case of improving their physical and mental health. The current survey revealed the opinion of the FPBs consumers in Thailand. This study concluded that FPBs are health promoting drink that is affordable in the daily life of Thai people. The FPBs prepared in Thailand did not report any massive adverse effects in Thailand. Till now the preparation and consumption of FPBs are followed in Thailand and not influenced by adverse effects; FPBs are considered safe for human consumption.
\end{abstract}

Keywords: fermented plant beverages; consumer satisfaction; health benefits; mental health.

Practical Application: To know the consumer' opinion on consumption and beneficial impact of fermented plant beverages in Thailand, which help to improve the production of fermented food products and its market.

\section{Introduction}

Fermented plant beverages (FPBs) are non-alcoholic FPBs due to the Lactic acid bacteria (LAB) mediated fermentation. The LAB fermented beverages are produced from a wide variety of plant based ingredients like cereals, fruits, and vegetables. The LAB fermented beverages are widely prepared and consumed throughout the world particularly in Thailand. Many people in Thailand believe that consumption of FPBs can prevent and cure sickness, and have anti-aging property (Peerajan et al., 2016). FPBs were initially produced for household use by the local people, and later they were commercialized due to the health benefits of FPBs. About > 3,500 different fermented products are available in the market and being consumed by the people over the world, and most of the FPBs and fermented dairy products are produced in Asian, African, and Eastern countries (Kabak \& Dobson, 2011). Many countries have unique FPBs regarding preparation, raw materials usage, and starter culture. The cereals based indigenous FPBs were reviewed and listed by Waters et al. (2015).

The main purpose of fermenting the food and consuming the fermented products are the preservation of food from spoilage for quite a long period, and enhancement of the nutritional value of food, respectively. The process of making FPBs detoxify the adverse compounds of plant raw materials like phytates, tannins, and polyphenols (Gadaga et al., 1999). The consumers of FPBs are trusting that FPBs can prevent obesity, diabetics, diseases related to gastro intestinal tract, and even cancer. Some studies reported that the raw materials and compounds of traditional FPBs have anti-lung cancer, anti-colon cancer, and anti-breast cancer properties (McGovern et al., 2010; Takagi et al., 2015).

Furthermore, the lifestyle of the consumer, an increase in food allergies, food intolerance, malabsorption, and diet-related diseases like cardiovascular disease, hyper blood pressure affected the fermented food market during the last decade, especially dairy products. FPBs are good enough to supplement the dietary antioxidants, dietary fiber, minerals, vitamins, and other micronutrients to needy people (Waters et al., 2015).

Thai FPBs are commonly manufactured as per the ancient formulation with industrialized procedures for commercial marketing throughout the country. Thai Community Product Standards (TCPS) (No. 481/2004) regulates the quality of the local products, especially fermented beverages. As per the regulation of TCPS, the quality criteria for Thai FPBs are with the limitations of ethanol content $(\leq 3 \% \mathrm{v} / \mathrm{v})$, methanol content $(\leq 3 \% \mathrm{v} / \mathrm{v}), \mathrm{pH}(\leq 4.3)$, and no viable cells of Salmonella spp., Staphylococcus aureus, and Clostridium perfringens in $50 \mathrm{~g}$, $1 \mathrm{ml}$, and $0.1 \mathrm{~g}$ of sample, respectively. Moreover, the presence of Escherichia coli should be $<2.2$ MPN index per $100 \mathrm{ml}$ of 
sample, and Yeast and mold count should be $\leq 100$ colonies per $1 \mathrm{~g}$ of sample, respectively. Recently, we have examined and reported the physical and chemical safety of commonly used FPBs of Thailand and most of the FPBs are safe to consume except some Morinda based drinks, and the study also recommends the benign serving size of FPBs (Chaiyasut et al., 2017).

In Thailand, public media like newspapers, organic and agriculture society, and community education centers are promoting the production and use of ethnic FPBs. Thus far, as per our knowledge, there was no detailed report on opinion and consumers' preference for the FPBs in Thailand. Accordingly, the current study was conducted to know the real status, satisfaction of consumers, and the impact of FPB consumption by surveying the representatives from all the parts of Thailand.

\section{Methodology}

About two hundred and thirty-five ( 235$)$ consumers were randomly selected to represent all the part of Thailand. Every person was individually interviewed by one of our field researchers, and the information was collected for the prescribed questions (Appendix 1). The questions were about consumption methods, effects of FPBs, consumers' satisfaction, and benefits of FPBs along with their identity. The representative consumers were asked to write the answers to the questionnaire by themselves, or an interrogator filled the form as per the oral response of consumers. All the collected information were cumulated and verified twice with an independent researcher to avoid the human error. The data is represented in percentage for every executed parameter, and these are presented in tables and figures.

\section{Results and discussion}

\subsection{Basic information of participated consumers of FPBs}

The independent researchers were assigned to meet the voluntary consumers of FPBs, and the information was collected via a questionnaire. The basic information about the representative volunteers is detailed in Table 1. Among 235 people, a sum of 105 male (44.7\%) and 130 female (55.3\%) consumers are involved in the study with the age group ranging from $<20$ to $>79$ years old. About 10 (4.2\%), 77 (32.7\%), 98 (41.7\%), 46 (19.6\%), and 4 (1.8\%) of consumers are under the age group of $<20,20-39,40-59$, $60-79$, and $>79$ years old, respectively. Regarding the education background, 75 (31.9\%), 31 (13.2\%), 34 (14.5\%), 63 (26.8\%), $8(3.4 \%), 8(3.4 \%), 11(4.7 \%)$, and $5(2.1 \%)$ of the consumers have completed primary school, high school, high vocational certification, bachelor degree, master degree, other certificates, anonymous (the information was not provided by the consumer) and not educated, respectively. About 57 (24.3\%), 51(21.7\%), $30(12.8 \%), 69(29.3 \%)$, and $28(11.9 \%)$ of the consumers are agriculturist, merchant, government officer/retired government officials, freelance, and anonymous, respectively (Table 1). The study population represented the people from different age group, educational and occupational status, and region of the country. Most of the consumers were from northeastern (43.8\%), and central (36.6\%) part of Thailand while the representatives from southern Thailand was very limited (0.9\%). The regional distribution of the consumers, who participated in the present study did not mirror the actual status of FPB consumption and consumers in southern Thailand.

\subsection{Rationale and frequency of FPBs consumption}

The opinion of consumers about the rationale of FPBs consumption was collected and categorized (Figure 1a). The consumers reported that they were consuming the FPBs for the betterment of health conditions and to treat the health problems such as diabetes (10.2\%), skin disorder (6\%), hypertension (18.7\%), kidney diseases (5.1\%), heart diseases (5.5\%), dyslipidemia (5.1\%), asthma/allergy (17.9\%), cancer $(0.9 \%)$, burn/scald (2.1\%), other diseases (18.7\%), anorexia (11.9\%), diarrhea (6.8\%), vertigo (17\%), insomnia (20.4\%), constipation (23.4\%), headache/fever (20.4\%), and other conditions (22.1\%). All the consumers mentioned more than one health problem for which they were drinking FPBs. About 43 , and $41.3 \%$ of consumers consume FPBs to treat musculoskeletal pain, and exhaustion, respectively (Figure 1a).

Table 1. Basic information about the surveyed consumers of FPB in Thailand.

\begin{tabular}{|c|c|c|}
\hline \multirow{2}{*}{ Criteria } & \multicolumn{2}{|c|}{ Consumers } \\
\hline & Numbers & Percentage \\
\hline \multicolumn{3}{|l|}{ Gender } \\
\hline Male & 105 & 44.7 \\
\hline Female & 130 & 55.3 \\
\hline \multicolumn{3}{|l|}{ Age (year) } \\
\hline$<20$ & 10 & 4.2 \\
\hline $20-39$ & 77 & 32.7 \\
\hline $40-59$ & 98 & 41.7 \\
\hline $60-79$ & 46 & 19.6 \\
\hline$>79$ & 4 & 1.8 \\
\hline \multicolumn{3}{|l|}{ Education } \\
\hline Primary school & 75 & 31.9 \\
\hline High school & 31 & 13.2 \\
\hline $\begin{array}{l}\text { High Vocational } \\
\text { Certificate }\end{array}$ & 34 & 14.5 \\
\hline Bachelor degree & 63 & 26.8 \\
\hline Master degree & 8 & 3.4 \\
\hline Other & 8 & 3.4 \\
\hline Anonymous & 11 & 4.7 \\
\hline None & 5 & 2.1 \\
\hline \multicolumn{3}{|l|}{ Occupation } \\
\hline Agriculturist & 57 & 24.3 \\
\hline Merchant & 51 & 21.7 \\
\hline $\begin{array}{l}\text { Government officer / } \\
\text { Retired Government } \\
\text { Official }\end{array}$ & 30 & 12.8 \\
\hline Freelance & 69 & 29.3 \\
\hline Anonymous & 28 & 11.9 \\
\hline \multicolumn{3}{|l|}{ Region of hometown } \\
\hline Northern & 22 & 9.4 \\
\hline Central & 86 & 36.6 \\
\hline Southern & 2 & 0.9 \\
\hline North eastern & 103 & 43.8 \\
\hline Eastern & 9 & 3.8 \\
\hline Anonymous & 13 & 5.5 \\
\hline
\end{tabular}


a)

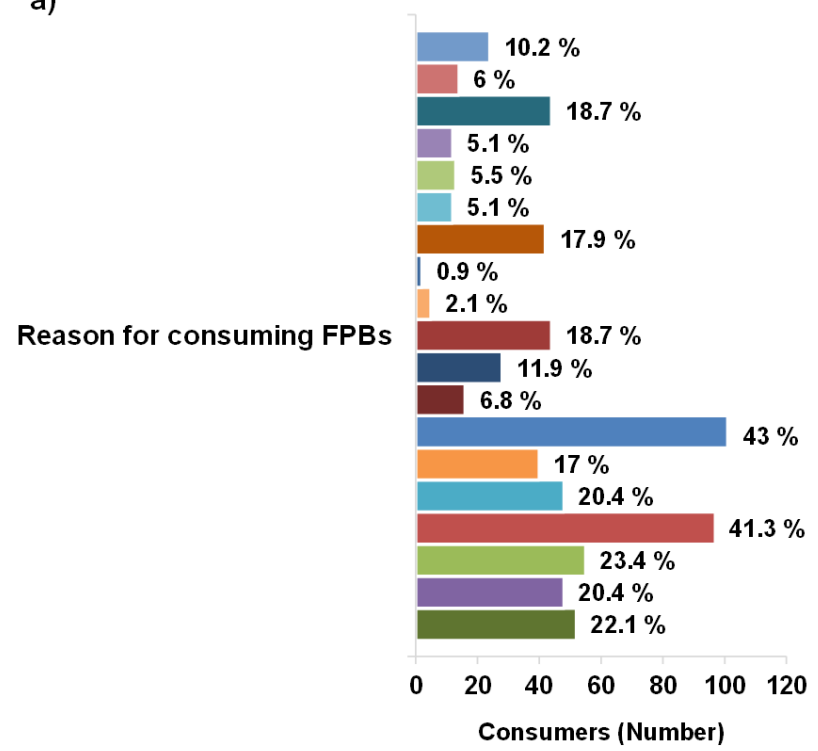

b)

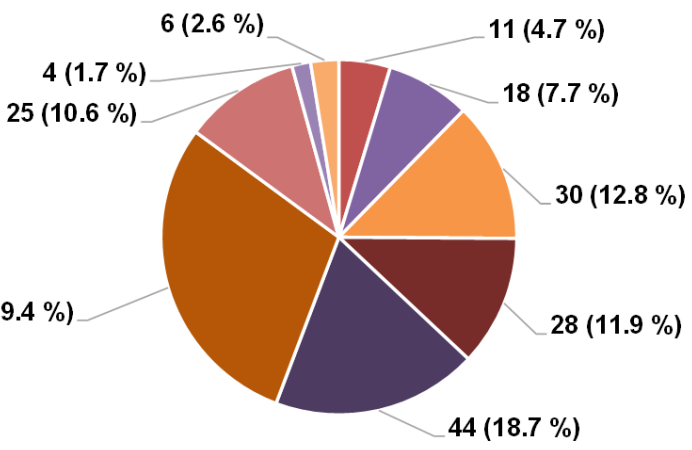

c) Anonymous $6 \%$

$44(18.7 \%)$
- Diabetes

- Skin disorders

- Hypertension

- Kidney diseases

- Heart diseases

- Dyslipidemia

- Asthma/allergy

- Cancer

- Burn/scald

- Other diseases

- Anorexia

- Diarrhea

- Musculoskeletal pain

- Vertigo

- Insomnia

- Exhaustion

- Constipation

- Headache/fever

- Other conditions

\section{- Once a month}

- 1-2 times per month

- 1-2 times per week

- Almost everyday

- Once a day

- 2 times per day

- 3 times per day

- More than 1 time per day

- Anonymous

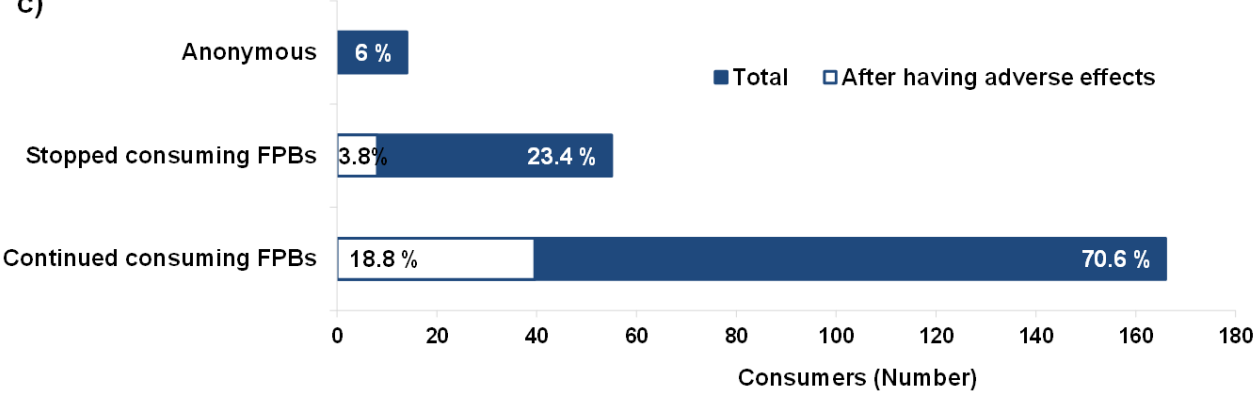

Figure 1. The rationale of FPBs consumption among the surveyed Thai consumers (a), the consumption regularity (b), the continuity of FPBs consumption (c). Percentage value represents the number of consumers.

Worldwide, fermented foods and beverages occupy about one-third of the human diet (Borresen et al., 2012). A consumer' sensory survey regarding selection of Gochujang (Korean soybean and grain-based fermented food with red pepper) as one of the food in their diet revealed that the modification of flavor like reduced hotness, promote the selection of the food by UK consumers (Burgess, 2014), which indicated that the selection of fermented food attributed to many characteristic features of the food.

The efficiency of the FPBs also depends on the dose and frequency of the consumption. Thus, the information about the consumption regularity of FPBs from the consumers was collected. The majority of the people ( 69 out of $235 ; 29.4 \%$ ) reported that they consume 2 servings per day, regularly. Subsequently, 44 (18.7\%), $30(12.8 \%), 28(11.9 \%)$, and $25(10.6 \%)$ consumers stated that they consume once a day, 1-2 servings per week, almost every day, and 3 servings per day, respectively (Figure 1b). There was no consistency in the serving size (volume of the consumption) among the consumers of FPBs, and it depended on the economic issues and availability of the product at the time of acquisition.

The continuation of FPBs consumption was influenced by the beneficial and adverse effects being gained by the consumers because of the FPBs. About 23.4\% of people terminated the 
FPBs drinking habits for multiple reasons, among them, 3.8\% of the consumers stopped the consumption of FPBs due to some adverse effects. About $70.6 \%$ of consumers continued the consumption of FPBs among which $18.8 \%$ people faced some of the adverse effects (Figure 1c). The detailed scientific report on adverse effect of FPBs is not available. The probiotic strains isolated form the FPBs of Thailand was not harmful to experimental animals (Duangjitcharoen et al., 2009).

\subsection{Impact of FPBs on health status of consumers}

The consumers of FPBs experienced some of the adverse effects such as drowsiness (6.8\%), flushing (6.0\%), unusual bad odor of stool (4.7\%), flatulence (4.3\%), diarrhea (3.8\%), vertigo (3.4\%), rashes or itching (1.7\%), anxiety (1.7\%), acne or melisma (1.7\%), pain at particular body part (1.3\%), dry mouth (1.3\%), constipation (0.9\%), headache (0.9\%), nausea/vomiting $(0.9 \%)$, insomnia $(0.9 \%)$, and other conditions (frequent urination, and edema) (8.5\%) during the first week of consumption, while 164 consumers $(69.8 \%)$ did not experience any of these adverse effects. After a week, $\sim 84.7 \%$ of consumers were proceeding with their normal life without any hostile effects from FPB consumption, but some of the consumers (18 in no.) faced problems like flatulence $(1.7 \%)$, diarrhea $(0.9 \%)$, vertigo $(0.9 \%)$, rashes $(1.3 \%)$, headache $(0.4 \%)$, and other conditions $(2.6 \%)$, which is negligible (Table 2).

The consumption of FPBs increased the severity of some of the illness, such as drowsiness, arthralgia, opportunistic infection in HIV patients, kidney disease, asthma/allergy, hypertension, and other conditions (frequent urination, and edema), but the worsening of health condition was recorded in $\sim 0.4-2.1 \%$ of consumers (Figure 2a).

a)

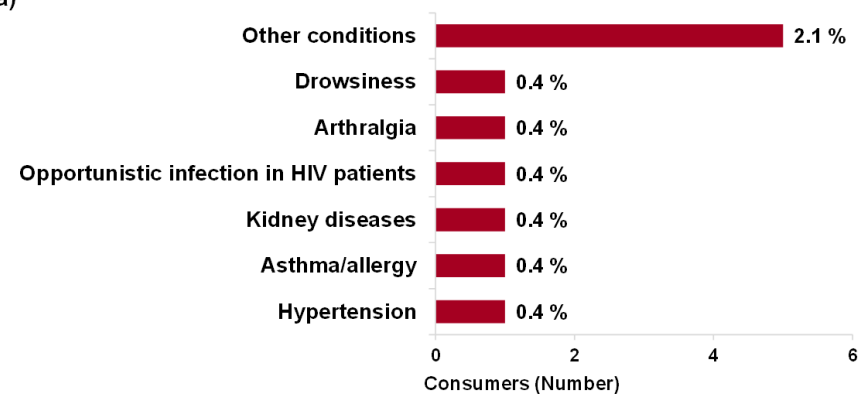

b)

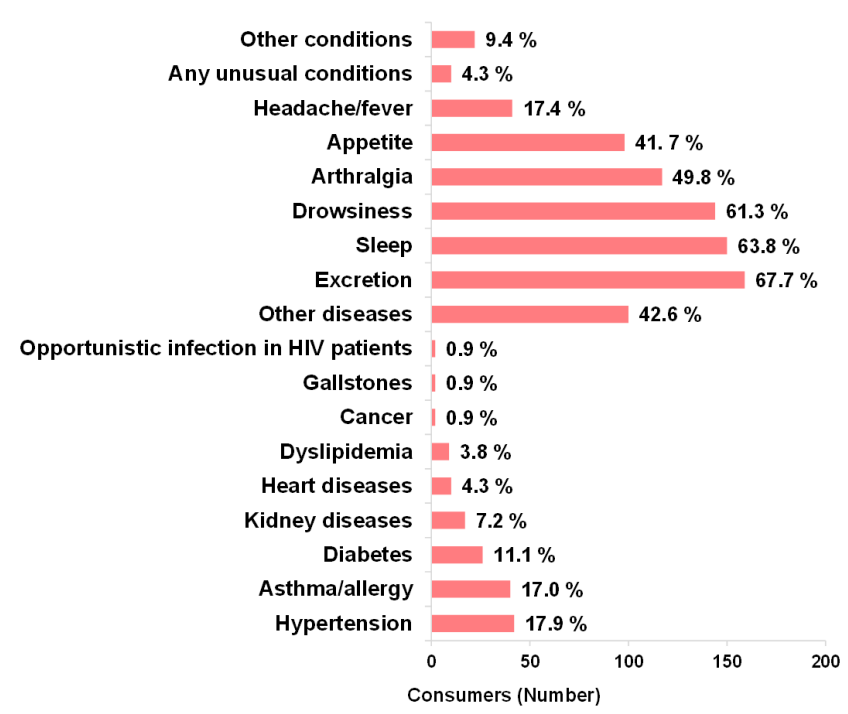

c)

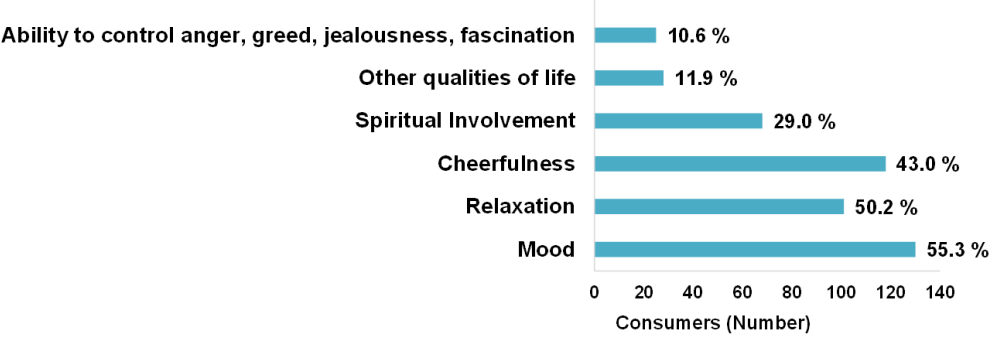

Figure 2. Harmful (a), and beneficial effects (improvement in health conditions) (b) to the consumers during FPBs consumption, and changes in the psychological status of the consumers (c). Percentage value represents the number of consumers. 
Table 2. The effects of FBPs consumption.

\begin{tabular}{|c|c|c|}
\hline \multirow{2}{*}{ Effects } & \multicolumn{2}{|c|}{ Consumers } \\
\hline & Numbers & Percentage \\
\hline \multicolumn{3}{|l|}{ During first week of consumption } \\
\hline Normal & 164 & 69.8 \\
\hline Drowsiness & 16 & 6.8 \\
\hline Flushing & 14 & 6.0 \\
\hline Unusual bad odor or black stool & 11 & 4.7 \\
\hline Flatulence & 10 & 4.3 \\
\hline Diarrhea & 9 & 3.8 \\
\hline Vertigo & 8 & 3.4 \\
\hline Rash or itching & 4 & 1.7 \\
\hline Anxiety & 4 & 1.7 \\
\hline Acne or melisma & 4 & 1.7 \\
\hline Body pain & 3 & 1.3 \\
\hline Dry mouth or throat & 3 & 1.3 \\
\hline Constipation & 2 & 0.9 \\
\hline Headache & 2 & 0.9 \\
\hline Nausea, vomiting & 2 & 0.9 \\
\hline Insomnia & 2 & 0.9 \\
\hline $\begin{array}{l}\text { Other conditions (such as } \\
\text { frequent Urination, and edema) }\end{array}$ & 20 & 8.5 \\
\hline \multicolumn{3}{|l|}{ After a week of consumption } \\
\hline None & 199 & 84.7 \\
\hline Flatulence & 4 & 1.7 \\
\hline Rash & 3 & 1.3 \\
\hline Vertigo & 2 & 0.9 \\
\hline Diarrhea & 2 & 0.9 \\
\hline Headache & 1 & 0.4 \\
\hline Other conditions & 6 & 2.6 \\
\hline
\end{tabular}

Most of the consumers drank FPBs for the improvement of their health conditions. Some conditions such as excretion (67.7\%), insomnia (63.8\%), drowsiness (61.3\%), arthralgia (49.8\%), appetite (41.7\%), hypertension (17.9\%), headache/fever (17.4\%), asthma/allergy (17.0\%), diabetes (11.1\%), other conditions (9.4\%), kidney diseases (7.2\%), heart diseases (4.3\%), dyslipidemia (3.8\%), etc., became better because of the consumption of FPB (Figure 2b), which suggested that the FPBs are effective in terms of health promoting property.

Vietnamese traditional fermented foods are reported as rich sources of probiotic and beneficial microbes. The short term and long term fermented foods are used. Dua chua (short term fermented fruit or vegetable), and Tuong (long-term fermented Soybean sauce paste) were the major fermented plant based food of Vietnam. The health promoting properties such as anticancer, antimicrobial activities are attributed to the residing natural microbes especially lactic acid bacteria (Anh, 2015). A detailed study on consumption of Kimchi, (famous Korean salt-fermented food and a good source of minerals, vitamins, fibers, and other trace nutrients) suggested that the intake of kimchi containing a large volume of salt was not associated with hypertension, indeed, high consumption of kimchi helps to neutralize the salt imbalance (Song \& Lee, 2014).

The people in the Eastern Himalayas region prepare and use traditional soybean based fermented foods namely Kinema, hawaijar, tungrymbai, bekang, and peruyaan. Even though it is prepared by the natural fermentation process, Bacillus subtilis is the major microbe involved in the process, because the usage of starter enhances the process and achieve the product earlier. The sticky fermented soybean provides the nutrient-rich, low-fat content diet with the antioxidant property that nourishes the consumer' health (Tamang, 2015).

The influence of FPB consumption on the psychological status of the surveyed consumers was collected. The consumers registered that the consumption of FPBs improved the mood $(55.3 \%)$, relaxation $(50.2 \%)$, cheerfulness $(43.0 \%)$, spiritual involvement (29.9\%), and quality of the life (11.9\%), ability to control the anger, greed, jealousness, fascination (10.6\%), and other mental conditions (6.8\%) (Figure 2c).

The influence of fermented food on the mental health of the human has already been reviewed (Selhub et al., 2014). It is known that the changes in the microbiome of the human cause psychological changes, and the diet play the major role in gut microbiome fluctuations (Dash et al., 2015; Kennedy et al., 2016). The foodborne bacterial infection like Cronobacter sakazakii infection was also reported showing impact on the cognitive behavior of the experimental animal (Sivamaruthi et al., 2015). The preparation of FPBs in hygienic condition might provide the health benefits to the consumers. Ultimately, the survey results suggested that the consumption of FPBs improved the mental health of the consumers by regulating the microbiome. The variations in the opinion were due to the consumption of different FPB products with different composition and microbial load.

\subsection{Commonly available FPBs in Thailand, storage, and economic feasibility}

We surveyed most common and popular FPBs of Thailand. A sum of 226 products was identified as popular fermented drinks in Thailand, among which Morinda (128), and black galingale (38) based products occupied the major FPB market in Thailand. About $95(42.0 \%)$, and $96(42.5 \%)$ products were in the form of a concentrate and were sour, and sweet taste, respectively. A sum of 35 (15.5\%) FPBs was under the ready to drink categories (Table 3 ).

The storage temperature of FPBs plays the critical role in preserving the beneficial effects of the raw materials. Most of the surveyed consumers reported that they stored the FPBs (both concentrated (57.9\%) and ready to drink products (18.7\%)) at room temperature, and about $28.1 \%$ and $18.3 \%$ of people stored the concentrated and ready to drink FPB products at refrigerator $\left(\sim 4{ }^{\circ} \mathrm{C}\right)$ temperature, respectively. Some of the consumers did not disclose the proper storage conditions of their FPB products (Figure 3a). The storage condition of the product varies on the availability of refrigerator and basic knowledge of the preservation method of FPBs. The majority of the surveyed consumers conveyed that the consumption of FPBs did not affect their economic status, and it was effective (88.1\%), but $6.4 \%$ of the people reported that the FPBs was not economically feasible (Figure $3 b$ ).

\subsection{Overall consumer' satisfaction about FPBs}

The overall consumer' satisfaction about FPBs was collected with six different scales (from 5 star (excellent) to 1 star (poor), and unknown) and three different categories (about benefits, 
physical and economical properties, and the status of the consumer after consumption of FPBs).

A sum of 94, 73, and 40 consumers reported that the benefits of FPBs are very good, excellent, and good, respectively.
The general acceptability of FPB consumption by the surveyed consumers was "very good" (Table 4). The results suggested that the majority of consumers of FPBs are, in general, were satisfied with the current quality of FPBs.

a)

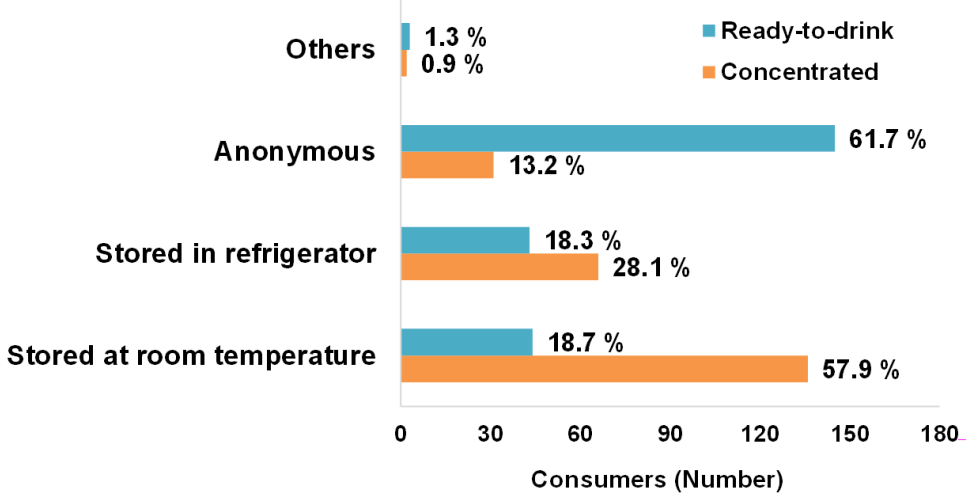

b)

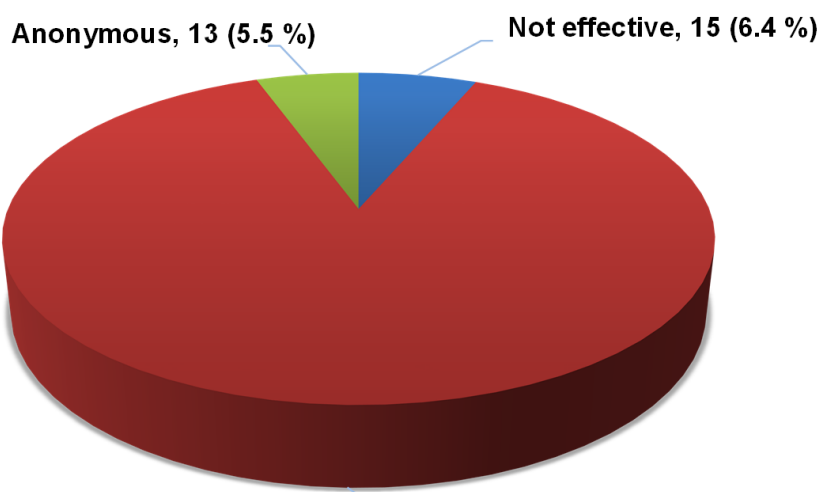

Effective, 207 (88.1\%)

Figure 3. The storage pattern of FPBs in Thailand (a), and the impact of FPBs consumption on the economic status of the surveyed consumers (b). Percentage value represents the number of consumers.

Table 3. The popularity of FPBs in Thailand.

\begin{tabular}{|c|c|c|c|}
\hline \multirow{3}{*}{ Main Formula } & \multicolumn{3}{|c|}{ Nature of the products } \\
\hline & \multicolumn{2}{|c|}{${ }^{\star}$ Concentrate } & \multirow{2}{*}{ Ready to drink } \\
\hline & Sour & Sweet & \\
\hline Morinda based products & $56(24.8 \%)$ & $48(21.2 \%)$ & $24(10.6 \%)$ \\
\hline Black galingale based products & $3(1.3 \%)$ & $35(15.5 \%)$ & - \\
\hline other & $36(15.9 \%)$ & $13(5.8 \%)$ & $11(4.9 \%)$ \\
\hline Subtotal & $95(42 \%)$ & $96(42.5 \%)$ & $35(15.5 \%)$ \\
\hline Total & 226 & & \\
\hline
\end{tabular}

${ }^{\star}$ The consumers have to prepare the drink from the fermented plant concentrates. The values are represented in numbers and in percentage.

Table 4. Consumers' satisfaction about FPBs benefits.

\begin{tabular}{|c|c|c|c|c|c|c|}
\hline \multirow{2}{*}{ Satisfaction } & \multicolumn{5}{|c|}{${ }^{*}$ Level of satisfaction (number of consumers (percentage)) } & \multirow{2}{*}{ Unknown } \\
\hline & 5 & 4 & 3 & 2 & 1 & \\
\hline Overall Satisfaction & $73(31.1)$ & $94(40.0)$ & $40(17.0)$ & $2(0.9)$ & $2(0.9)$ & $24(10.2)$ \\
\hline Taste & $53(22.6)$ & $92(39.1)$ & $65(27.7)$ & $10(4.3)$ & $2(0.9)$ & $13(5.5)$ \\
\hline Odor and color & $40(17.0)$ & $86(36.6)$ & $66(28.1)$ & $18(7.7)$ & $2(0.9)$ & $23(9.8)$ \\
\hline Price & $17(7.2)$ & $40(17.0)$ & $99(42.1)$ & $17(7.2)$ & $2(0.9)$ & $60(25.5)$ \\
\hline Appearance & $10(4.3)$ & $50(21.3)$ & $96(40.9)$ & $15(6.4)$ & $2(0.9)$ & $62(26.4)$ \\
\hline Consumption difficulty & $7(3.0)$ & $5(2.1)$ & $23(9.8)$ & $38(16.2)$ & $83(35.3)$ & $79(33.6)$ \\
\hline
\end{tabular}

${ }^{\star} 1-5$ represent the satisfaction levels. 5 indicates consumers were extremely satisfied with FPBs, and 1 indicates the satisfaction level is very poor. 


\section{Conclusion}

Even though, several studies detailed about the beneficial effects of fermented fruits, vegetables, and Lactic acid bacteria (Di Cagno et al., 2013; Swain et al., 2014). The opinion of FPB consumers may vary on the type and composition of product, and frequency of usage. The current survey results suggested that the fermented plant beverages of Thailand are in continuous use by the Thai people which was not entirely influenced by the adverse side effects of FPBs. Moreover, many surveyed consumers said that they recovered from several illnesses, for which they started consuming the FPBs. People's opinion on FPBs may change on the introduction of new products, advertisements, and other marketing artifices, but the popularity of the traditional Thai fermented beverages remains unchanged.

\section{Acknowledgements}

All the authors gratefully acknowledge the Faculty of Pharmacy and Chiang Mai University, Chiang Mai for the necessary support. PK also acknowledges the CMU Post-Doctoral Fellowship, Chiang Mai University, Chiang Mai, Thailand.

\section{References}

Anh, N. L. (2015). Health-promoting microbes in traditional Vietnamese fermented foods: a review. Food Science and Human Wellness, 4(4), 147-161. http://dx.doi.org/10.1016/j.fshw.2015.08.004.

Borresen, E. C., Henderson, A. J., Kumar, A., Weir, T. L., \& Ryan, E. P. (2012). Fermented foods: patented approaches and formulations for nutritional supplementation and health promotion. Recent Patents on Food, Nutrition \& Agriculture, 4(2), 134-140. PMid:22702745. http://dx.doi.org/10.2174/2212798411204020134.

Burgess, P. J. (2014). Modification of a traditional Korean food product (Gochujang) to enhance its consumer acceptability as an ethnic food. Journal of Ethnic Foods, 1(1), 13-18. http://dx.doi.org/10.1016/j. jef.2014.11.005.

Chaiyasut, C., Sivamaruthi, B. S., Peerajan, S., Sirilun, S., Chaiyasut, K., \& Kesika, P. (2017). Assessment of heavy metals, minerals, alcohol, and fusel oil content of selected fermented plant beverages of Thailand. International Food Research Journal, 24(1), 126-133.

Dash, S., Clarke, G., Berk, M., \& Jacka, F. N. (2015). The gut microbiome and diet in psychiatry: focus on depression. Current Opinion in Psychiatry, 28(1), 1-6. PMid:25415497. http://dx.doi.org/10.1097/ YCO.0000000000000117.

Di Cagno, R., Coda, R., De Angelis, M., \& Gobbetti, M. (2013). Exploitation of vegetables and fruits through lactic acid fermentation. Food Microbiology, 33(1), 1-10. PMid:23122495. http://dx.doi. org/10.1016/j.fm.2012.09.003.

Duangjitcharoen, Y., Kantachote, D., Ongsakul, M., Poosaran, N., \& Chaiyasut, C. (2009). Potential use of probiotic Lactobacillus plantarum SS2 isolated from a fermented plant beverage: safety assessment and persistence in the murine gastrointestinal tract.
World Journal of Microbiology \& Biotechnology, 25(2), 315-321. http://dx.doi.org/10.1007/s11274-008-9894-0.

Gadaga, T. H., Mutukumira, A. N., Narvhus, J. A., \& Feresu, S. B. (1999). A review of traditional fermented foods and beverages of Zimbabwe. International Journal of Food Microbiology, 53(1), 1-11. PMid:10598109. http://dx.doi.org/10.1016/S0168-1605(99)00154-3.

Kabak, B., \& Dobson, A. D. W. (2011). An introduction to the traditional fermented foods and beverages of Turkey. Critical Reviews in Food Science and Nutrition, 51(3), 248-260. PMid:21390945. http://dx.doi. org/10.1080/10408390903569640.

Kennedy, P. J., Murphy, A. B., Cryan, J. F., Ross, P. R., Dinan, T. G., \& Stanton, C. (2016). Microbiome in brain function and mental health. Trends in Food Science \& Technology, 57, 289-301. http:// dx.doi.org/10.1016/j.tifs.2016.05.001.

McGovern, P. E., Christofidou-Solomidou, M., Wang, W., Dukes, F., Davidson, T., \& El-Deiry, W. S. (2010). Anticancer activity of botanical compounds in ancient fermented beverages. International Journal of Oncology, 37(1), 5-14. PMid:20514391. http://dx.doi. org/10.3892/ijo_00000647.

Peerajan, S., Chaiyasut, C., Sirilun, S., Chaiyasut, K., Kesika, P., \& Sivamaruthi, B. S. (2016). Enrichment of nutritional value of Phyllanthus emblica fruit juice using the probiotic bacterium, Lactobacillus paracasei HII01 mediated fermentation. Food Science and Technology (Campinas), 36(1), 116-123. http://dx.doi. org/10.1590/1678-457X.0064.

Selhub, E. M., Logan, A. C., \& Bested, A. C. (2014). Fermented foods, microbiota, and mental health: ancient practice meets nutritional psychiatry. Journal of Physiological Anthropology, 33(1), 2. PMid:24422720. http://dx.doi.org/10.1186/1880-6805-33-2.

Sivamaruthi, B.S., Madhumita, R., Balamurugan, K., \& Rajan, K. E. (2015). Cronobacter sakazakii infection alters serotonin transporter and improved fear memory retention in the rats. Frontiers in Pharmacology, 6, 188. http://dx.doi.org/10.3389/fphar.2015.00188.

Song, H. J., \& Lee, H. (2014). Consumption of kimchi, a salt fermented vegetable, is not associated with hypertension prevalence. Journal of Ethnic Foods, 1(1), 8-12. http://dx.doi.org/10.1016/j.jef.2014.11.004.

Swain, M. R., Anandharaj, M., Ray, R. C., \& Rani, R. P. (2014). Fermented fruits and vegetables of Asia: a potential source of probiotics. Biotechnology Research International, 2014, 250424. PMid:25343046. http://dx.doi.org/10.1155/2014/250424.

Takagi, A., Kano, M., \& Kaga, C. (2015). Possibility of breast cancer prevention: use of soy isoflavones and fermented soy beverage produced using probiotics. International Journal of Molecular Sciences, 16(5), 10907-10920. PMid:25984609. http://dx.doi.org/10.3390/ ijms160510907.

Tamang, J. P. (2015). Naturally fermented ethnic soybean foods of India. Journal of Ethnic Foods, 2(1), 8-17. http://dx.doi.org/10.1016/j. jef.2015.02.003.

Waters, D. M., Mauch, A., Coffey, A., Arendt, E. K., \& Zannini, E. (2015). Lactic acid bacteria as a cell factory for the delivery of functional biomolecules and ingredients in cereal-based beverages: a review. Critical Reviews in Food Science and Nutrition, 55(4), 503-520. PMid:24915367. http://dx.doi.org/10.1080/10408398.2012.660251. 
Appendix 1. Questioner form for the survey of fermented plant beverages (FPBs) consumers in Thailand.

Interview of FPBs consumers

\section{Basic information}

1.1 Gender $\quad \square$ Male $\quad \square$ Female

1.2 Age years

1.3 Education (specified)

$\square$ No $\square$ Primary school

$\square$ High school

$\square$ Vocational Certificate

$\square$ High Vocational Certificate

$\square$ Bachelor's degree

$\square$ Master's degree

$\square$ Doctor of Philosophy

$\square$ Others

1.4 Occupation

(You can answer more than one choice; if you have more than one job, you should specify what is your major job or minor job)

$\square$ Farmer

$\square$ Government officer

$\square$ State enterprise officer $\square$ Student

$\square$ Businessman/merchant

$\square$ Government employee

$\square$ Private company employee $\square$ Worker $\square$ Others ......

\subsection{Address}

House number.... Street.

Sub-district District. Province

Telephone number

1.6 You are a member of (you can choose more than)

$\square$ Cooperative: name

$\square$ Community network: name

$\square$ Temple: name.

$\square$ Community learning center: name

$\square$ Agriculture network: name

$\square$ Women group association: name

$\square$ Others

\section{Information about the consumption of FPBs}

2.1 What FPBs did you consume, and where you find it (In decreasing order of the preference)

\begin{tabular}{|c|c|c|c|c|c|}
\hline \multirow{2}{*}{ No. } & \multirow{2}{*}{ Name } & \multicolumn{2}{c|}{ Type } & \multirow{2}{*}{ Production site } \\
\cline { 3 - 5 } & & ${ }^{\star}$ Sour, concentrated & Sweet, concentrated & Ready-to-drink & \\
\hline & & & & & \\
\hline & & & & & \\
\hline & & & & \\
\hline
\end{tabular}

Sweet, concentrated means FPBs that were fermented until due time, then add syrup, honey, sugar

Ready-to-drink means concentrated FPBs that were diluted, sugar or honey was added and stored at low temperature

2.2 For what conditions or diseases did you start the use of FPBs? (you can choose more than one)

a. Conditions
$\square$ Diarrhea
$\square$ Constipation $\square$ Vertigo
$\square$ Musculoskeletal pain
$\square$ Exhaustion $\square$ Headache/fever
$\square$ Anorexia
$\square$ Insomnia $\quad \square$ Others ...... 
b. Diseases

$\begin{array}{lll}\square \text { Hypertension } & \square \text { Heart diseases } & \square \text { Diabetes } \\ \square \text { Asthma/allergy } & \square \text { Kidney diseases } & \square \text { Dyslipidemia } \\ \square \text { Cancer } & \square \text { Burn/scald } & \square \text { Skin disorders } \\ \square \text { Opportunistic infection in people with HIV } & \square \text { Others............. }\end{array}$

\section{The consumption frequency and other information}

3.1 consumption frequency
$\square$ Once a month
$\square$ 1-2 times per month
$\square$ 1-2 times per week
$\square$ Almost every day
$\square$ Every day (should be specified)

$\square$ Once a day

$\square 2$ times per day $\square 3$ times per day $\square 4$ times per day

$\square$ More than 4 times per day (specify)...

3.2 Do you consume FPBs continuously?

$\square$ Still consuming, since month year

$\square$ Stopped consuming, Duration of the consumption

Reason for discontinuation:

3.3 When you started consuming FPBs, Did you have any adverse reactions in the first week of consumption? (you can choose more than one)

$\square$ Normal/did not have any adverse effects $\square$ Dry mouth or throat $\square$ Drowsiness $\square$ Fever $\square$ Diarrhea

\begin{tabular}{|c|c|c|}
\hline$\square$ Constipation & $\square$ Flatulence & $\square$ Nausea/vomiting \\
\hline$\square$ Vertigo & $\square$ Rash or itching & $\square$ Flushing \\
\hline$\square$ Anxiety & $\square$ Headache & $\square$ Edema \\
\hline$\square$ Insomnia & $\square$ Acne, melasma & $\square$ Smelled or black stool \\
\hline
\end{tabular}

3.4 Which underlying disease got better after consuming FPBs? (you can choose more than one choice)
$\square$ None $\quad \square$ Hypertension $\quad \square$ Heart diseases
$\square$ Diabetes $\quad \square$ Asthma/allergy $\square$ Kidney diseases
$\square$ Dyslipidemia $\quad \square$ Cancer $\quad \square$ Gallstones, kidney diseases

$\square$ Opportunistic infection in people with HIV (specify)

$\square$ Others

Did you have any medical record or other examination from physicians? Explain.

3.5 Which conditions got better after consuming FPBs? (you can choose more than one)
$\square$ None
$\square$ Excretion $\quad \square$ Sleep $\quad \square$ Appetite
$\square$ Arthralgia $\quad \square$ Energetic $\quad \square$ Headache/fever
$\square$ Any unusual conditions (specify)
$\square$ Others 
3.6 Which conditions or diseases got better after consuming FPBs? (you can choose more than one)

$\square$ None
$\square$ Hypertension $\quad \square$ Heart diseases
$\square$ Diabetes
$\square$ Asthma/allergy $\square$ Kidney diseases
$\square$ Dyslipidemia

$\square$ Cancer

$\square$ Gallstones, kidney diseases

$\square$ Opportunistic infection in people with HIV (specify)

$\square$ Excretion $\square$ Sleep $\square$ Appetite

$\square$ Arthralgia $\square$ Drowsiness $\square$ Headache/fever

$\square$ Others

3.7 Did you have any adverse reactions after consuming for more than a week? (You can choose more than one choice)

$\square$ None

$\square$ Fever

$\square$ Diarrhea

$\square$ Flatulence

$\square$ Anorexia

$\square$ Nausea/vomiting

$\square$ Vertigo

$\square$ Headache

$\square$ Rash

$\square$ Alopecia

$\square$ Others

When you had an adverse reaction, did you stop consuming FPBs?

$\square$ Stopped consuming because

$\square$ Still consuming because

3.8 If you consumed concentrated FPBs, when did you completely consume each bottle?
$\square$........Days
$\square$ Stored at room temperature
$\square$ stored in refrigerator
$\square$ Others

How did you store ready-to-drink FPBs?

$\square$ Stored at room temperature $\square$ Stored in refrigerator

\section{Consumers' satisfaction of FPBs benefits}

Check $\sqrt{ }$ in the table which depend on your opinion or write your suggestion in the space below

\begin{tabular}{|c|c|c|c|c|c|c|}
\hline & 5 & 4 & 3 & 2 & 1 & 0 \\
\hline \multicolumn{7}{|l|}{ 4.1 Satisfaction of FPBs benefits } \\
\hline \multicolumn{7}{|l|}{ 4.2 Satisfaction of FPBs products } \\
\hline \multicolumn{7}{|l|}{ Taste } \\
\hline \multicolumn{7}{|l|}{ Odor and color } \\
\hline \multicolumn{7}{|l|}{ Price } \\
\hline \multicolumn{7}{|l|}{ Appearance of packaging } \\
\hline \multicolumn{7}{|l|}{ Consumption difficulty } \\
\hline Others (specified): & & & & & & \\
\hline
\end{tabular}

4.3 Did you think that consuming FPBs can help to improve your qualities of life?

$\square$ No

$\square$ Yes because FPBs can help with
$\square$ Cheerfulness
$\square$ Mood
$\square$ Relaxation

$\square$ Buddhist practice

$\square$ Mediation practice

$\square$ Letting yourselves on

$\square$ Others 
5. Problems or suggestions of the products that you used

Products:

Problems or suggestions:

6. Problems or suggestions that you want to report to Consumer Protection agents/government officers (Public Health Office) 